Рад примљен: 26. 6. 2021.

Рад прихваћен: 4. 9. 2021.

\begin{tabular}{|r|r}
$\begin{array}{c}\text { Оригинални } \\
\text { научни рад }\end{array}$ & $\begin{array}{r}\text { Milena B. Ivanuš Grmek } \\
\text { Monika M. Mithans } \\
\text { Polona C. Jančič Hegediš }\end{array}$ \\
\cline { 2 - 2 } & University of Maribor, Faculty of Education, Maribor, Slovenia
\end{tabular}

\title{
Analysis of Textbook use in 4th and 5th Grades of Primary School
}

\begin{abstract}
Summary: A modern trend in quality textbooks is to stimulate different areas of student development - social, cognitive, moral, and emotional, considering students' learning specifics. Textbooks are adapted to students if they consider their developmental level, experience and level of understanding; use appropriate language; encourage reading through comprehension, and include illustrations in the text (Marentič Požarnik, 2016). The quality of learning resources that students can also use to learn independently is important. The main purpose of the Slovenian project The Quality of Slovenian Textbooks (KaUc) is to develop textbook quality indicators for practical use in validation and evaluation processes. As part of the KaUč project, an empirical research was conducted on the research sample of 505 students, with its research aim to analyse the use of textbooks and workbooks in 4th and 5th grades of primary school. Based on the performed analyses, we can determine that the use of printed textbooks prevails in all educational subjects. Textbooks are most often used for the first foreign language subject, science and technology, and for social studies.
\end{abstract}

Keywords: Textbook, primary school, didactics, students.

\section{Introduction}

Textbooks have been used in schools from the times when schools had first occurred and until the present times, having a central place in school education. Their role in the historical development of education has been constantly changing, depending on social developments and changes in gener-

1 milena.grmek@um.si

al and subject-specific theory of learning and teaching (Skela, 2008). In terms of didactics, textbook can be understood as a textual learning medium, with its main feature to properly structure, process, and simplify scientific contents using didactic transformation, and to contribute, as a learning aid and learning resource, to the effectiveness of teaching and independent learning (Kovač et al., 2005). Malić (1992, p. 34) also believes that textbooks are

Copyright @ 2021 by the authors, licensee Teacher Education Faculty University of Belgrade, SERBIA.

This is an open access article distributed under the terms of the Creative Commons Attribution License (CC BY 4.0) (https://creativecommons.org/licenses/by/4.0/), which permits unrestricted use, distribution, and reproduction in any medium, provided the original paper is accurately cited. 
"irreplaceable school books, necessary in the process of school education, and an important aid for high-quality teaching and learning."

The project called For the Quality of Slovenian Textbooks (KaUč) is being implemented in Slovenia between 2017 and 2022. Textbooks are one of less examined research areas in the school field in Slovenia and, as a result, there are many shortcomings observed in understanding the use of textbooks. The main goal of the KaUč Project is to develop textbook quality indicators for practical use in validation and evaluation processes. In this paper, we are presenting a part of the Project in the context of textbook analysis. We are focusing on the use and features of textbooks as perceived by $4^{\text {th }}$ and $5^{\text {th }}$ grade primary school students.

\section{Textbook Definition}

"Textbook can be defined as a special type of professional literature determined by its content and target audience; and in broader terms, it is defined by the school system, as its content is 'determined' by the government through curricula, i.e. by content-related and operational goals of a subject or a subject area" (Turk Škraba, 2006, p. 31). Consequently, Aslan (2009, summarised from Ersoy and Şahin, 2012) considers textbooks educational materials that largely comply with required curricula. Nevertheless, there are differences between textbooks. The reason also lies in different understanding of the curricula that are designed on the basis of different pedagogical purposes as well as cultural and educational traditions (Van den Ham and Heinze, 2018).

In Article 2 of the Rules on the Approval of Textbooks (2015), a textbook is defined as a "basic teaching material aimed at achieving educational goals and knowledge standards defined in the curriculum or in the catalogue of knowledge. It supports teaching and learning through didactic and methodological organisation of the content, and through adapted art and graphic equipment. Text- book content and structure enable participants in education to learn independently and acquire different levels and types of knowledge. Every textbook is linked to a school subject or module and a certain educational level. Textbook is also a reading-book as a collection of texts chosen in line with the objectives of the curriculum." It can be used in printed or electronic form, or in both printed and electronic forms (Rules on the Approval of Textbooks, Article 2).

Kovač et al. (2005, p. 20) define textbooks as follows: "As a learning aid or learning resource, a textbook is a textual learning medium that, as part of educational technology, contributes to the effectiveness of teaching and independent learning." Its scientific content is properly structured, processed, and simplified (Kovač et al., 2005), as students have both poor prior knowledge on the given contents and their own characteristic rules of the cognitive process, which do not allow them to understand the given content in a didactically unprocessed form. This is also agreed upon by Milena Ivanuš Grmek (2003) who defines a textbook as a special learning book in which science is transformed in such a way that it is accessible to all students using the textbook. Štefanc (2005) believes that textbooks cannot be defined by a simple and unambiguous definition. It is, therefore, necessary to be satisfied with a rough definition that a textbook as a learning aid or learning resource is a textual learning medium. Therefore, as part of educational technology, textbooks contribute to the effectiveness of teaching and independent learning.

Based on different definitions, Skela (1993, pp. 201-202) formulated a single textbook definition, and wrote that textbook was:

- "A standard book presenting the content of the educational subject and determining the forms of activities;

- It contains data on specific area and is used by pupils or students studying this subject; 
- A book written with the aim to be used by students in schools, and being in accordance with their psycho-physical maturity;

- A book in which the professional content is given to a student with the use of didactic instruments;

- A mass, basic, and compulsory school book;

- (Primarily) textual learning aid;

- A help to students in their intellectual development;

- A book that is almost daily used by students for education and self-education;

- A learning aid, which is most frequently used."

\section{Textbook Role}

The role of textbook in education has changed over the years. In the past, its didactic function had primary role. At a later stage, textbook became an integral part of methodological and didactic materials, having educational, informative, conative, cognitive, and emotional functions (Jurman, 1999).

Textbook is an important educational aid in transferring knowledge to new generations (Palló, 2006). It can be included in a teacher's teaching process (Štefanc, 2005), as for a teacher, textbook is "one of the teaching aids that help achieving optimal learning outcomes" (Kovač et al., 2005, p. 31). Teachers can successfully include textbook in all stages of the learning process on condition that they thoroughly know the subject matter, master the textbook, and have didactic qualifications (Kovač et al., 2005). Textbook helps both teachers and students achieve their goals determined in the subject curriculum (Turk Škraba, 2006, p. 31).

In her research, Rianda Herlinda (2014) found that teachers attribute a fundamental role to textbooks in a teaching process. It is a good textbook that is often the basis for high-quality teaching, since teachers (of mathematics) often strictly follow the textbook in their presentations of the subject material, as observed by the analysis of research works dealing with interactions between textbooks and teachers. It is also important to note that the choice of textbook affects both the choice of didactic strategies and the choice of contents (Linor Lea Hadar, 2017). Topics not covered by textbooks are seldom addressed in lessons (Schmidt et. al., 1997, summarised from van den Ham and Heinze, 2018), as teachers largely use textbooks as a tool to conduct lessons (Hung Lau et al., 2018).

According to Poljak (1983), textbook writers need to know modern didactic theory to provide a high-quality didactic design of textbooks. They have to know the structure of the learning process and its rules. Moreover, it is important to consider the principle of learning activity, requiring textbooks to be equipped with a variety of activities enabling students to develop their knowledge through their own activity and, therefore, learn to learn (Poljak, 1983). Textbook writers have to pay attention also to the textbook external design, language, writing style as well as artistic and graphic design (Ivanuš Grmek, 2003). It is important to design textbooks to offer students assistance with learning the subject matter, while complementing or expanding other sources of education at the same time. Only if textbooks are properly didactically designed, teachers will be able to use them effectively in all stages of the learning process (Poljak, 1983).

\section{Purpose of the Research}

The purpose of the research was to examine textbooks, using the sample of $4^{\text {th }}$ and $5^{\text {th }}$ grade students, and covering the following aspects:

1. Use of textbooks: textbook type, frequency of use, personal preferences;

2. Perceived textbook characteristics. 
We paid attention to the textbooks used for all the subjects taught in $4^{\text {th }}$ and $5^{\text {th }}$ grades (SLO, MAT, TJ1, LUM, GUM, DRU, NIT, GOS²).

\section{Methodology}

A descriptive non-experimental empirical study was performed.

\section{Research sample}

The survey involved 505 students from seven primary schools in different regions, of which 261 (51.7 \%) were boys and 244 (48.3\%) were girls. The average age of students was 10.0 years $(\mathrm{MIN}=9$, $\mathrm{MAX}=11, \mathrm{SD}=0.5) .224(44.4 \%)$ students attended $4^{\text {th }}$ grade and $277(54.9 \%)$ attended $5^{\text {th }}$ grade. Four students $(0.8 \%)$ did not indicate the grade attended. Students' average marks in the previous school year were the following: $4.32(\mathrm{MIN}=1, \mathrm{MAX}=5$, $\mathrm{SD}=0.8)$ in mathematics, $4.36(\mathrm{MIN}=1, \mathrm{MAX}=5$, $\mathrm{SD}=0.8)$ in Slovenian language, and $4.35(\mathrm{MIN}=1$, $\mathrm{MAX}=5, \mathrm{SD}=0.9$ ) in the first foreign language. In order to make a rough assessment of the involved students' socio-economic conditions, we collected some additional data on the property and habits of the families included in the survey. A majority of the students involved in the survey report having their own room (74\%), their own desk (90.3\%), their own books (92.6\%), and internet access (92.4\%) at home. $55.9 \%$ of students report having their own magazines at home. $10 \%$ of students reported using a mobile phone for more than three hours a day, $23.1 \%$ for 1 to 3 hours, $50 \%$ for less than an hour, and $16.9 \%$ of students reported not having a mobile phone. A majority of the students reported not having a tablet computer (50.6\%), desktop computer $(51.8 \%)$ or laptop computer $(49.8 \%)$ or using it for less than one hour a day, respectively (35.3-

2 Subject abbreviations used: SLO - Slovenian language, MAT - mathematics, TJ1 - first foreign language; LUM - fine arts, GUM - music art, DRU - social studies, NIT - science and technology, GOS - housekeeping
$37.6 \%$ for different types of computers). Between 3.6 and $4.4 \%$ of the students reported using a computer (tablet, desktop, or laptop) for more than three hours a day.

Most students report learning English as their first foreign language; a smaller proportion of the students $(34 ; 6.5 \%)$ report German as their first foreign language.

\section{Data collection process}

We used an online survey questionnaire comprising sets of survey questions and sets of rating scales. The questionnaire validity is based on considering previous scientific findings and a review by practising teachers. The questionnaire reliability was ensured by precise, specific questions, clear instructions for completing the questionnaire, and the use of probing. The questionnaire objectivity is attributed to the fact that the survey was carried out online (individually, without the researcher's presence) and the questionnaire comprised a prevailing number of closed-ended questions, enabling the answers to be understood objectively.

\section{Data processing procedure}

The data were processed using descriptive statistics procedures (frequency distributions, basic descriptive statistics). Some measures of inferential statistics ( $t$-test for dependent samples) were used to check relationships between variables.

\section{Results}

In accordance with each aspect of the research problem, we are presenting the results by subsections, namely, first showing the data related to textbook use (textbook type, frequency of use in classroom and at home, personal preferences), and then the data on perceived textbook characteristics. 


\subsection{Textbook Use}

\section{Textbook type}

Table 1 shows the students' answers to the question about the types of textbooks they use in specific subjects.

Table 1: Textbook types used by students in specific subjects

\begin{tabular}{|c|c|c|c|c|c|c|c|c|c|c|c|c|}
\hline & \multicolumn{2}{|c|}{$\begin{array}{l}\text { Printed } \\
\text { textbook }\end{array}$} & \multicolumn{2}{|c|}{ e-textbook } & \multicolumn{2}{|c|}{$\begin{array}{l}\text { Printed and } \\
\text { e-textbook }\end{array}$} & \multicolumn{2}{|c|}{ No textbook } & \multicolumn{2}{|c|}{$\begin{array}{l}\text { I do not have } \\
\text { the subject }\end{array}$} & \multicolumn{2}{|c|}{ Total } \\
\hline & $f$ & $\%$ & $\mathrm{f}$ & $\%$ & $\mathrm{f}$ & $\%$ & $\mathrm{f}$ & $\%$ & $\mathrm{f}$ & $\%$ & $\mathrm{f}$ & $\%$ \\
\hline SLO & 184 & 37.2 & 19 & 3.8 & 24 & 4.9 & 260 & 52.6 & 7 & 1.4 & 494 & 100 \\
\hline MAT & 187 & 38.0 & 13 & 2.6 & 25 & 5.1 & 256 & 52.0 & 11 & 2.2 & 492 & 100 \\
\hline TJ1 & 404 & 82.4 & 14 & 2.9 & 34 & 6.9 & 36 & 7.3 & 2 & 0.4 & 490 & 100 \\
\hline LUM & 70 & 14.3 & 7 & 1.4 & 5 & 1.0 & 381 & 78.1 & 25 & 5.1 & 488 & 100 \\
\hline GUM & 131 & 27.0 & 14 & 2.9 & 17 & 3.5 & 307 & 63.3 & 16 & 3.3 & 485 & 100 \\
\hline DRU & 434 & 88.0 & 13 & 2.6 & 34 & 6.9 & 9 & 1.8 & 3 & 0.6 & 493 & 100 \\
\hline NIT & 428 & 86.8 & 13 & 2.6 & 44 & 8.9 & 7 & 1.4 & 1 & 0.2 & 493 & 100 \\
\hline GOS & 196 & 39.8 & 4 & 0.8 & 7 & 1.4 & 66 & 13.4 & 219 & 44.5 & 492 & 100 \\
\hline
\end{tabular}

Table 1 shows that most students report not using textbooks in fine arts and music as well as in Slovenian language and mathematics. Most students report using printed textbooks in the first foreign language, social studies, and science and technology. The use of printed textbooks prevails in all subjects; and only a small portion of students reported using e-textbooks (alone or together with printed textbooks). The fact that in each subject a small portion of the students report not having the subject indicates a questionable validity of these answers; namely, these subjects are compulsory in $4^{\text {th }}$ and $5^{\text {th }}$ grades, with the exception of the housekeeping subject that $4^{\text {th }}$ grade students really do not have.

\section{Frequency of using textbooks}

Furthermore, we were interested in how often students use textbooks for specific subjects both in the classroom and at home.

Table 2 shows the students' answers to the question of how often they use textbooks in each subject both in the classroom and at home.

The table shows that students most frequently use the first foreign language textbook in the classroom, which is followed by textbooks for sci- ence and technology, social studies, housekeeping, mathematics, Slovenian language, music, and fine arts. A similarity is observed in using textbooks at home; namely students report that textbook is most frequently used for social studies, and science and technology, which is followed by the first foreign language, housekeeping, mathematics, Slovenian language, music, and fine arts. Most students report using textbooks never or occasionally in all subjects, both in classroom and at home.

We also checked whether there are statistically significant differences in using textbooks for specific subjects in classroom and at home. The results of the t-test for dependent samples showed that differences between the frequency of textbook use were statistically significant in all the subjects; students report using textbooks more often in classroom than at home $\left(\mathrm{t}_{\mathrm{SLO}}=3.097 ; \mathrm{df}_{\mathrm{SLO}}=453\right.$; $\mathrm{p}_{\mathrm{SLO}}=0.002 ; \mathrm{t}_{\mathrm{MAT}}=3.780 ; \mathrm{df}_{\mathrm{MAT}}=446 ; \mathrm{p}_{\mathrm{MAT}}=0.000 ;$ $\mathrm{t}_{\mathrm{TJ} 1}=11.503 ; \mathrm{df}_{\mathrm{TJ} 1}=451 ; \mathrm{p}_{\mathrm{TJ1}}=0.000 ; \mathrm{t}_{\mathrm{LUM}}=5.527 ;$ $\mathrm{df}_{\mathrm{LUM}}=431 ; \mathrm{p}_{\mathrm{LUM}}=0.000 ; \mathrm{t}_{\mathrm{GUM}}=4.645 ; \mathrm{df}_{\mathrm{GUM}}=431 ;$ $\mathrm{p}_{\mathrm{GUM}}=0.000 ; \mathrm{t}_{\mathrm{DRU}}=5.976 ; \mathrm{df}_{\mathrm{DRU}}=463 ; \mathrm{p}_{\mathrm{DRU}}=0.000$; $\mathrm{t}_{\mathrm{NIT}}=7.451 ; \mathrm{df}_{\mathrm{NIT}}=463 ; \mathrm{p}_{\mathrm{NIT}}=0.000 ; \mathrm{t}_{\mathrm{GOS}}=6.888 ; \mathrm{df}-$ GOS $\left.=257 ; \mathrm{p}_{\mathrm{GOS}}=0.000\right)$. 
Table 2: Frequency of using textbooks in the classroom and at home by subjects: frequencies and descriptive statistics

\begin{tabular}{|c|c|c|c|c|c|c|c|c|c|c|c|c|}
\hline & \multicolumn{2}{|c|}{1 - Never } & \multicolumn{2}{|c|}{2 - Occasionally } & \multicolumn{2}{|c|}{3 - Frequently } & \multicolumn{2}{|c|}{ 4-Always } & \multicolumn{2}{|c|}{$\mathrm{M}$} & \multicolumn{2}{|c|}{$\mathrm{SD}$} \\
\hline & $\begin{array}{c}\text { In } \\
\text { class- } \\
\text { room } \\
\mathrm{f} ; \%\end{array}$ & $\begin{array}{c}\text { At } \\
\text { home } \\
\text { f; } \%\end{array}$ & $\begin{array}{c}\text { In } \\
\text { class- } \\
\text { room } \\
\mathrm{f} ; \%\end{array}$ & $\begin{array}{c}\text { At } \\
\text { home } \\
\text { f; \% }\end{array}$ & $\begin{array}{c}\text { In } \\
\text { class- } \\
\text { room } \\
\mathrm{f} ; \%\end{array}$ & $\begin{array}{c}\text { At } \\
\text { home } \\
\text { f; \% }\end{array}$ & $\begin{array}{c}\text { In } \\
\text { class- } \\
\text { room } \\
\mathrm{f} ; \%\end{array}$ & $\begin{array}{c}\text { At } \\
\text { home } \\
\text { f; } \%\end{array}$ & $\begin{array}{c}\text { In } \\
\text { class- } \\
\text { room }\end{array}$ & $\begin{array}{c}\text { At } \\
\text { home }\end{array}$ & $\begin{array}{c}\text { In } \\
\text { class- } \\
\text { room }\end{array}$ & $\begin{array}{c}\text { In } \\
\text { class- } \\
\text { room }\end{array}$ \\
\hline SLO & $\begin{array}{l}279 \\
58.1\end{array}$ & $\begin{array}{l}305 \\
66.2\end{array}$ & $\begin{array}{l}134 \\
27.9\end{array}$ & $\begin{array}{l}100 \\
21.7\end{array}$ & $44 ; 9.2$ & $\begin{array}{l}42 ; \\
9.1\end{array}$ & $23 ; 4.8$ & $14 ; 3.0$ & 1.61 & 1.49 & 0.84 & 0.78 \\
\hline MAT & $\begin{array}{l}272 \\
57.4\end{array}$ & $\begin{array}{l}282 \\
61.3\end{array}$ & $84 ; 17.7$ & $93 ; 20.2$ & $72 ; 15.2$ & $53 ; 11.5$ & $46 ; 9.7$ & $32 ; 7.0$ & 1.77 & 1.64 & 1.03 & 0.94 \\
\hline TJ1 & $41 ; 8.5$ & $70 ; 15.1$ & $83 ; 17.3$ & $\begin{array}{l}181 \\
39.0\end{array}$ & $\begin{array}{l}220 \\
45.7\end{array}$ & $\begin{array}{l}143 ; \\
30.8\end{array}$ & $\begin{array}{l}137 ; \\
28.5\end{array}$ & $70 ; 15.1$ & 2.94 & 2.46 & 0.89 & 0.92 \\
\hline LUM & $\begin{array}{l}392 ; \\
84.8\end{array}$ & $\begin{array}{l}418 \\
93.7\end{array}$ & $54 ; 11.7$ & $19 ; 4.3$ & $11 ; 2.2$ & $\begin{array}{c}6 ; \\
1.3\end{array}$ & $5 ; 1.1$ & $3 ; 0.7$ & 1.20 & 1.09 & 0.52 & 0.39 \\
\hline GUM & $\begin{array}{l}300 \\
66.1\end{array}$ & $\begin{array}{l}322 \\
70.8\end{array}$ & $68 ; 15.0$ & $87 ; 19.1$ & $65 ; 14.3$ & $\begin{array}{l}32 \\
7.0\end{array}$ & $21 ; 4.6$ & $14 ; 3.1$ & 1.57 & 1.42 & 0.90 & 0.76 \\
\hline DRU & $14 ; 2.9$ & $43 ; 9.1$ & $\begin{array}{l}162 ; \\
33.3\end{array}$ & $\begin{array}{l}193 ; \\
41.0\end{array}$ & $\begin{array}{l}224 \\
46.1\end{array}$ & $\begin{array}{l}163 ; \\
34.6\end{array}$ & $86 ; 17.7$ & $72 ; 15.3$ & 2.79 & 2.56 & 0.76 & 0.86 \\
\hline NIT & $5 ; 1.0$ & $38 ; 8.0$ & $\begin{array}{l}160 \\
32.9\end{array}$ & $\begin{array}{l}210 \\
44.4\end{array}$ & $\begin{array}{l}232 \\
47.7\end{array}$ & $\begin{array}{l}155 \\
32.8\end{array}$ & $89 ; 18.3$ & $70 ; 14.8$ & 2.83 & 2.54 & 0.73 & 0.84 \\
\hline GOS & $66 ; 24.2$ & $93 ; 35.2$ & $82 ; 30.0$ & $92 ; 34.8$ & $71 ; 26.0$ & $46 ; 17.4$ & $54 ; 19.8$ & $33 ; 12.5$ & 2.41 & 2.07 & 1.06 & 1.01 \\
\hline
\end{tabular}

\section{Students' preferences}

When asked the open-ended question about which textbook they use most frequently, a majority of students answers that social studies textbook is used most frequently (155), followed by textbooks for science and technology (130), English language (91), mathematics (50), Slovenian language (27), housekeeping (24), musical arts (8), and fine arts (1).

When asked the next open-ended question about which textbook they prefer, most students answer that science and technology textbook (163) is most liked, followed by textbooks for social sciences (111), English language (107), mathematics (46), Slovenian language (30), housekeeping (17), musical arts (10), and German language (6).

\section{Perceived Textbook Characteristics}

Table 3 shows the students' answers to the question which requires them to evaluate textbooks for different subjects by aspects. Students had to assess whether the textbook for each subject corresponds to the description or not. Table 3 shows the frequencies and shares indicating how many times each textbook was chosen as corresponding to the given description. 
Table 3: Characteristics of textbooks for each subject as perceived by students: frequencies and shares

\begin{tabular}{|c|c|c|c|c|c|c|c|c|}
\hline Textbook characteristics & $\begin{array}{l}\text { SLO } \\
\text { f; \% }\end{array}$ & $\begin{array}{c}\text { MAT } \\
\text { f; } \%\end{array}$ & $\begin{array}{l}\text { TJ1 } \\
\text { f; \% }\end{array}$ & $\begin{array}{c}\text { LUM } \\
\text { f; } \%\end{array}$ & $\begin{array}{c}\text { GUM } \\
\text { f; } \%\end{array}$ & $\begin{array}{l}\text { DRU } \\
\text { f; \% }\end{array}$ & $\begin{array}{l}\text { NIT } \\
\text { f; \% }\end{array}$ & $\begin{array}{l}\text { GOS } \\
f ; \%\end{array}$ \\
\hline Textbook includes contents of my interest. & $\begin{array}{l}147 \\
34.0\end{array}$ & $\begin{array}{l}147 \\
34.0\end{array}$ & $\begin{array}{l}327 \\
75.7\end{array}$ & $41 ; 9.5$ & $\begin{array}{c}96 \\
20.3\end{array}$ & $\begin{array}{l}345 \\
72.8\end{array}$ & $\begin{array}{l}367 \\
77.4\end{array}$ & $86 ; 32.7$ \\
\hline Textbook includes contents from everyday life. & $\begin{array}{l}175 \\
47.6\end{array}$ & $\begin{array}{c}89 \\
24.2\end{array}$ & $\begin{array}{l}211 \\
57.3\end{array}$ & $10 ; 2.7$ & $\begin{array}{c}50 \\
11.0\end{array}$ & $\begin{array}{l}376 \\
82.6\end{array}$ & $\begin{array}{l}323 \\
71.0\end{array}$ & $\begin{array}{l}121 ; \\
48.0\end{array}$ \\
\hline $\begin{array}{l}\text { Textbook encourages me to think about unknown } \\
\text { things and their explanation. }\end{array}$ & $\begin{array}{l}125 \\
31.5\end{array}$ & $\begin{array}{l}149 \\
37.5\end{array}$ & $\begin{array}{l}271 \\
68.3\end{array}$ & $18 ; 4.5$ & $\begin{array}{l}73 \\
16.6\end{array}$ & $\begin{array}{l}313 ; \\
71.3\end{array}$ & $\begin{array}{l}342 ; \\
77.9\end{array}$ & $85 ; 35.0$ \\
\hline Textbook motivates me to learn. & $\begin{array}{l}120 \\
30.5\end{array}$ & $\begin{array}{l}157 \\
39.8\end{array}$ & $\begin{array}{l}274 \\
69.5\end{array}$ & $15 ; 3.8$ & $\begin{array}{c}85 \\
20.3\end{array}$ & $\begin{array}{l}292 ; \\
69.7\end{array}$ & $\begin{array}{l}310 \\
74.0\end{array}$ & $74 ; 32.3$ \\
\hline $\begin{array}{l}\text { Textbook encourages me to seek new ways to } \\
\text { solve individual problems. }\end{array}$ & $\begin{array}{l}138 ; \\
35.3\end{array}$ & $\begin{array}{l}166 ; \\
42.5\end{array}$ & $\begin{array}{l}228 \\
58.3\end{array}$ & $18 ; 4.6$ & $\begin{array}{c}63 \\
15.4\end{array}$ & $\begin{array}{l}288 \\
70.2\end{array}$ & $\begin{array}{l}279 \\
68.0\end{array}$ & $75.33 ; 8$ \\
\hline $\begin{array}{l}\text { Textbook allows me to connect knowledge among } \\
\text { different subjects. }\end{array}$ & $\begin{array}{l}154 \\
38.9\end{array}$ & $\begin{array}{l}161 ; \\
40.7\end{array}$ & $\begin{array}{l}255 \\
64.4\end{array}$ & $23 ; 5.8$ & $\begin{array}{l}76 \\
17.9\end{array}$ & $\begin{array}{l}306 ; \\
72.0\end{array}$ & $\begin{array}{l}320 \\
75.3\end{array}$ & $90 ; 39.3$ \\
\hline $\begin{array}{l}\text { Textbook allows me to connect knowledge within } \\
\text { a specific subject. }\end{array}$ & $\begin{array}{l}154 \\
36.6\end{array}$ & $\begin{array}{l}163 \\
38.7\end{array}$ & $\begin{array}{l}267 \\
63.4\end{array}$ & $24 ; 5.7$ & $\begin{array}{c}88 \\
20.7\end{array}$ & $\begin{array}{l}322 ; \\
75.6\end{array}$ & $\begin{array}{l}306 ; \\
71.8\end{array}$ & $92 ; 39.3$ \\
\hline $\begin{array}{l}\text { Textbook helps me find necessary data and } \\
\text { information. }\end{array}$ & $\begin{array}{l}166 \\
38.2\end{array}$ & $\begin{array}{l}167 \\
38.4\end{array}$ & $\begin{array}{l}309 \\
79.0\end{array}$ & $14 ; 3.2$ & $\begin{array}{l}76 \\
16.6\end{array}$ & $\begin{array}{l}354 \\
77.1\end{array}$ & $\begin{array}{l}364 \\
79.3\end{array}$ & $\begin{array}{l}110 \\
43.7\end{array}$ \\
\hline $\begin{array}{l}\text { Textbook encourages me to search for } \\
\text { information on the internet. }\end{array}$ & $153 ; 48$ & $\begin{array}{l}100 \\
31.3\end{array}$ & $\begin{array}{l}194 \\
60.8\end{array}$ & $15 ; 5.6$ & $\begin{array}{c}64 \\
17.7\end{array}$ & $\begin{array}{l}237 \\
65.7\end{array}$ & $\begin{array}{l}242 ; \\
67.0\end{array}$ & $52 ; 27.2$ \\
\hline Textbook takes into account my prior knowledge. & $\begin{array}{l}138 \\
38.5\end{array}$ & $\begin{array}{l}172 ; \\
44.6\end{array}$ & $\begin{array}{l}261 ; \\
67.6\end{array}$ & $27 ; 7.0$ & $\begin{array}{l}94 ; \\
23.6\end{array}$ & $\begin{array}{l}291 \\
73.1\end{array}$ & $\begin{array}{l}288 \\
72.4\end{array}$ & $84 ; 38.2$ \\
\hline $\begin{array}{l}\text { Textbook allows me to learn by watching, } \\
\text { listening, and making. }\end{array}$ & $\begin{array}{l}145 \\
37.3\end{array}$ & $\begin{array}{l}109 \\
28.8\end{array}$ & $\begin{array}{l}274 \\
70.4\end{array}$ & $\begin{array}{c}65 \\
16.7\end{array}$ & $\begin{array}{c}91 \\
22.9\end{array}$ & $\begin{array}{l}223 \\
52.7\end{array}$ & $\begin{array}{l}320 \\
75.7\end{array}$ & $91 ; 39.1$ \\
\hline $\begin{array}{l}\text { Photos, pictures, and sketches in textbook help me } \\
\text { learn. }\end{array}$ & $163 ; 37$ & $\begin{array}{l}161 \\
36.5\end{array}$ & $\begin{array}{l}340 ; \\
77.1\end{array}$ & $31 ; 7$ & $\begin{array}{c}94 \\
20.4\end{array}$ & $\begin{array}{l}378 ; \\
82.2\end{array}$ & $\begin{array}{l}357 ; \\
77.6\end{array}$ & $\begin{array}{l}126 ; \\
49.8\end{array}$ \\
\hline Textbook teaches me to learn independently. & $\begin{array}{l}156 \\
37.7\end{array}$ & $\begin{array}{l}169 \\
40.8\end{array}$ & $\begin{array}{l}313 ; \\
75.6\end{array}$ & $14 ; 3.4$ & $\begin{array}{c}85 \\
19.9\end{array}$ & $\begin{array}{l}324 \\
75.9\end{array}$ & $\begin{array}{l}319 ; \\
74.7\end{array}$ & $89 ; 38.5$ \\
\hline Textbook helps me improve my reading. & $\begin{array}{l}227 \\
\mathbf{5 3 . 0}\end{array}$ & $\begin{array}{l}102 ; \\
23.8\end{array}$ & $\begin{array}{l}303 \\
70.8\end{array}$ & $12 ; 2.8$ & $\begin{array}{c}87 \\
20.2\end{array}$ & $\begin{array}{l}355 \\
82.4\end{array}$ & $\begin{array}{l}323 \\
74.9\end{array}$ & $\begin{array}{l}105 \\
44.9\end{array}$ \\
\hline $\begin{array}{l}\text { Textbook helps me improve comprehension of } \\
\text { what I have read. }\end{array}$ & $\begin{array}{l}200 \\
47.3\end{array}$ & $\begin{array}{l}104 \\
24.6\end{array}$ & $\begin{array}{l}313 \\
74.0\end{array}$ & $9 ; 2.1$ & $\begin{array}{c}88 \\
20.4\end{array}$ & $\begin{array}{l}337 ; \\
78.0\end{array}$ & $\begin{array}{l}330 \\
76.4\end{array}$ & $\begin{array}{l}103 \\
43.0\end{array}$ \\
\hline $\begin{array}{l}\text { Textbook encourages me to behave nicely to } \\
\text { schoolmates, teachers, parents, and others. }\end{array}$ & $\begin{array}{l}206 \\
62.6\end{array}$ & $\begin{array}{c}65 \\
19.8\end{array}$ & $\begin{array}{l}149 \\
45.3\end{array}$ & $13 ; 4$ & $\begin{array}{c}55 \\
13.7\end{array}$ & $\begin{array}{l}321 \\
79.9\end{array}$ & $\begin{array}{l}183 ; \\
45.5\end{array}$ & $74 ; 35.1$ \\
\hline $\begin{array}{l}\text { Textbook encourages me to behave well to the } \\
\text { environment, teaching aids and equipment. }\end{array}$ & $\begin{array}{l}190 \\
53.2\end{array}$ & $\begin{array}{c}79 ; \\
22.1\end{array}$ & $\begin{array}{l}199 ; \\
55.7\end{array}$ & $22 ; 6.2$ & $\begin{array}{l}55 \\
12.9\end{array}$ & $\begin{array}{l}285 \\
66.6\end{array}$ & $\begin{array}{l}312 ; \\
72.9\end{array}$ & $69 ; 30.0$ \\
\hline Textbook helps me learn new words. & $\begin{array}{l}169 \\
43.1\end{array}$ & $\begin{array}{l}123 \\
27.0\end{array}$ & $\begin{array}{l}377 \\
82.9\end{array}$ & $26 ; 5.7$ & $\begin{array}{l}120 \\
26.3\end{array}$ & $\begin{array}{l}368 \\
80.5\end{array}$ & $\begin{array}{l}351 ; \\
76.8\end{array}$ & $\begin{array}{l}130 \\
51.8\end{array}$ \\
\hline
\end{tabular}

\footnotetext{
Note. Shares above $50 \%$ are marked in bold.
} 
Table 3 shows that the majority of students do not attribute the offered positive attributes to most textbooks. Exceptions include textbooks for the first foreign language, social studies, and science and technology, to which a majority of students attributed almost all of the positive descriptors offered. More than half of the students also estimated that the Slovenian language textbook enables them to improve their reading, and encourages them to behave nicely to people as well as the (learning) environment, while the housekeeping textbook enables them to learn new words.

\section{Discussion}

By surveying the $4^{\text {th }}$ and $5^{\text {th }}$ grade students in the school year, we examined the use of textbooks in each subject from several aspects (textbook type, frequency of textbook use, perceived textbook characteristics, students' preferences).

Based on the analyses carried out, we find that according to the students, the use of printed textbooks prevails in all subjects; and only a small proportion of students reported using e-textbooks (alone or together with printed textbooks). As some authors point out (e.g., Štefanc, 2005), we also find that textbooks still play an extremely important role in schools. Students need to be guided through the learning content adapted to their developmental characteristics and their prior knowledge. Modern communication and information technology in learning and teaching only contributes to a more varied lessons and helps a teacher adapting them more easily to students. According to Židan (1996), in the past, a textbook was the only source of information in addition to teacher's explanation, while in today's school, textbooks no longer play the role of the only information provider. The development of modern communication and information technology and easier access to information offered by the World Wide Web is changing both learning and teaching and the role of textbooks in this process (Kreuh, Kač, and Mohorčič, 2011).

The results of the survey also show that the share of the students that report not using textbook in a foreign language, social studies, and science and technology is lower than in fine and musical arts, Slovenian language, and mathematics.

Most students report using textbooks never or occasionally in all subjects, both in the classroom and at home. Both in the classroom and at home, students most frequently use textbooks for the first foreign language, science and technology, and social studies. Students also report using textbooks in all subjects more often in the classroom than at home. Considering the fact that textbooks are more intended for students than teachers, textbooks are in the function of learning or student's learning activities (Štefanc, 2005). Textbooks combine both the informative and formative functions, as they provide knowledge, while enabling the development of abilities, skills, and values (Kukanja Gabrijelčič, 2015). Textbooks should initially arouse students' interest in comprehension and learning; i.e., they should perform a motivational function (Kovač et al., 2005). Moreover, they should include information about what students need to do before they start dealing with a new subject matter. Textbooks that follow this didactic requirement, therefore, represent a source of information for students' preparatory work, which either a teacher can include in the lessons or students can do at home. An introduction into a new subject matter takes a little time; therefore, this part of the text has to be concise (Poljak, 1983). When introducing a new subject matter, textbooks should contribute to the "retrieval and reflection of prior knowledge, which is the basis for good comprehension of the content at a later stage" (Kovač et al., 2005, p. 32). At the next stage, i.e., discussing a new subject matter, the textbook role is strengthened. This stage aims at acquiring knowledge and, therefore, this part has to be carefully didactically designed. The content has to be designed 
to help students acquire knowledge, while complementing and expanding the teacher's explanation. Textbook authors have to design the desired knowledge in such a manner as to allow students a logical overview. They have to highlight the key points and present them in the form of subtitles in a logical sequence, making the basic content structure of the topic evident to students at first glance (Poljak, 1983). Textbooks have to be designed to ensure the repetition of knowledge, as it is the only way to ensure sustainability of knowledge. Textbook authors can draw students' attention to important parts of the text by using different fonts in writing and printing. Attention to the repetition can be drawn by creating generalisations, summaries, graphics, etc. (Poljak, 1983).

According to the students' preferences recorded in the survey, most students report that they like science and technology textbooks the most, while they most often use social studies textbook. Students most positively assess the characteristics of the first foreign language, social studies, and science and technology textbooks.

In the function of learning, textbooks can only be successful if adapted to students and vice versa, because this is the only way for students to learn to use effective learning strategies. Therefore, textbook writers have to pay attention to the developmental stage or level of understanding of the students to whom the textbook is intended. They have to use an intelligible language without unnecessary foreign words and form short sentences. They have to structure the topic properly, and provide a transparent text using titles and subtitles. They have to encourage reading with comprehension, and higher cognitive activities in students, using various tasks, questions, summaries, and glossaries (Marentič Požarnik, 2019). Each learning topic has to enable students to independently determine the level of their acquired knowledge, i.e. self-control, which textbook authors can ensure by creating tasks aimed at checking student's knowledge or comprehension of the subject matter (Poljak, 1983).

\section{Conclusion}

To sum up, based on the results of our research, we find that printed textbooks are still very often used in lessons in the $4^{\text {th }}$ and $5^{\text {th }}$ grades of primary school. The obtained results are an important basis for investigation of the use and role of textbooks in the process of education. Furthermore, under the KaUč Project, we examined and analysed the use and role of textbooks from teachers' viewpoint. In further implementation of the KaUč Project (For the Quality of Slovenian Textbooks), we are now developing indicators aimed at determining the quality of textbooks at several educational levels, using all the analyses of textbook use - among both students and teachers.

\section{References}

- Ersoy, F. \& Şahin, T. (2012). Examination of Social Studies Textbooks in terms of Approaches of Values Education. Educational Sciences: Theory \& Practice, 12 (2), 1547-1558. Retrieved November 25, 2020. from www: https://files.eric.ed.gov/fulltext/EJ987860.pdf

- Hadar, L. L. (2017). Opportunities to learn: Mathematics textbooks and students' achievements. Studies in Educational Evaluation, 55, 153-166. Retrieved March 11, 2021. from www: https://www.sciencedirect.com/ science/article/abs/pii/S0191491X17300949

- Herlinda, R. (2014). The Use of Textbook in Teaching and Learning Process: A Case Study of Two EYL Teachers. Paper presented at: TEFLIN International Conference. Retrieved February 12, 2021. from www: https://pdfs. semanticscholar.org/bbb2/76b93aa1dcfe4b5648a90ddf098b32cdb0e2.pdf 
- Hung Lau, K., Lam, T., Hon Kam, B., Nkhoma, M., Richards, J. \& Thomas, S. (2018). The role of textbook learning resources in e-learning: A taxonomic study. Computers \& Education, 118, 10-24. Retrieved March 11, 2021. from www: https://www.sciencedirect.com/science/article/pii/S0360131517302403

- Ivanuš Grmek, M. (2003). Učbeniški kompleti v prvem triletju devetletne osnovne šole. Sodobna pedagogika, 54 (5), 74-89.

- Jurman, B. (1999). Kako narediti dober učbenik: na podlagi antropološke vzgoje. Ljubljana: Jutro.

- Kovač, M., K. Šebart, M., Krek, J., Štefanc, D. \& Vidmar, T. (2005). Učbeniki in družba znanja. Ljubljana: Center za študij edukacijskih strategij, Pedagoška fakulteta, Univerza v Ljubljani.

- Kreuh, N., Kač, L. \& Mohorčič, G. (2011). Izhodišča za izdelavo e-učbenikov. Ljubljana: Zavod RS za šolstvo. Retrieved November 25, 2020. from www: http://www.dlib.si/stream/URN:NBN:SI:docXZNAX2LS/86256557-d2eb-46a9-9fb6-c268dbdf6ad7/PDF

- Kukanja-Gabrijelčič, M. (2015). Učbenik po meri učenca?: mednarodna primerjalna analiza vprašanj in nalog v učbenikih za zgodovino. Annales: analiza istrske in mediteranske študije = annali di Studi istriani e mediterranei = Annals for Istrian and Mediterranean studies, 25 (2), 385-398. Retrieved November 11, 2020. from www: http://www.dlib.si/details/URN:NBN:SI:doc-MHBW4NAM

- Malić, J. (1992). Vloga učbenika pri pouku. V: Željko, J. (Ed.). Učbeniki danes in jutri: prispevki s srečanja avtorjev učbenikov DZS Bled, 11 September 1991 (33-40). Ljubljana: DSZ.

- Marentič Požarnik, B. (2019). Psihologija učenja in pouka: od poučevanja k učenju. Ljubljana: DZS.

- Palló, G. (2006). Encyclopedia as Textbook. Science \& Education, 15 (7-8), 779-799. Retrieved February 12, 2021. from www: https://link.springer.com/article/10.1007\%2Fs11191-004-1998-9

- Pravilnik o potrjevanju učbenikov (2015). Official Gazette of RS, No 34/2015, 27/2017.

- Skela, J. (1993). Vloga učbenika v izobraževalnem procesu in njegova evalvacija. V: Štrukelj, I. (Ed.). Jezik tako in drugače (200-211). Ljubljana: Društvo za uporabno jezikoslovje Slovenije.

- Skela, J. (2008). Vrednotenje učbenikov angleškega jezika z vidika kognitivne teorije učenja. In: Skela, J. (Ed.). Učenje in poučevanje tujih jezikov na Slovenskem: pregled sodobne teorije in prakse (154-178). Ljubljana: Tangram.

- Štefanc, D. (2005). Učbenik z vidika didaktične teorije: značilnosti, funkcije, kakovost in problematika potrjevanja $=$ The textbook from the aspect of didactic theory: characteristics, function, quality and problems of approving. Sodobna pedagogika, 56 (4), 172-185.

- Turk Škraba, M. (2006). Učbenik kot prvina učnega procesa. Vzgoja in izobraževanje, 37 (5), 31-34.

- Van den Ham, A.-K. \& Heinze, A. (2018). Does the textbook matter? Longitudinal effects of textbook choice on primary school students' achievement in mathematics. Studies in Educational Evaluation, 59, 133140. Retrieved March 11, 2021. from www: https://www.sciencedirect.com/science/article/pii/ S0191491X18301007

- Židan, A. (1996). Metadidaktično poučevanje in učenje družboslovja. Ljubljana: FDV. 
Милена Б. Ивануш Грмек

Моника М. Митханс

Полона Ц. Јанчић Хегедиш

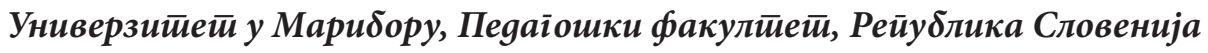

\section{АНАЛИЗА УПОТРЕБЕ УЩБЕНИКА У ЧЕТВРТОМ И ПЕТОМ РАЗРЕДУ ОСНОВНЕ ШКОЛЕ}

Улоїа уибеника у иситоријском развоју образована сииално се меюа у зависностии оя

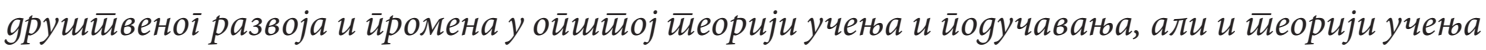
и йоgучаваюа засебних школских ирреgметиа (Skela, 2008). Kaga је реч о gияакиичии, уибе-

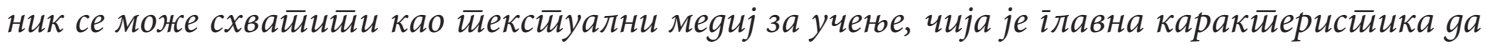

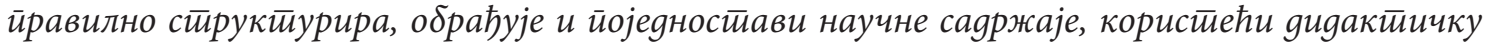
иррансформацију, и gа доиринесе, као йомоћ у учену и ресурс за учене, ефикасностии настиаве и самостиалном учену (Коvас̌ і sar., 2005). Учлану 2. Правилника о одобравағу уибеника уибеник је gефинисан као „основни настиавни матиеријал усмерен на йостизане образовних иильева и сиианgарgа знань дефинисаних настиавним йланом и ироірамом или кайалоїом

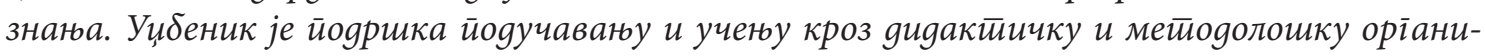
заиију саяржаја и иррилаі̄ођену тиковну и визуелну оирему. Саgржај и сйрукйура уибеника омоїћавају ученицима gа самостиално уче и сиичу различите нивое и врстие знань. Уибеник је йовезан са школским ирреgметиом или мояулом и одређеним образовним нивоом. Уибеник је

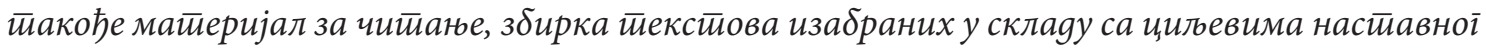
ирроірама“" (Pravilnik o potrjevanju učbenikov, 2015: člen 2). Може се корисииитии у ийамйаном

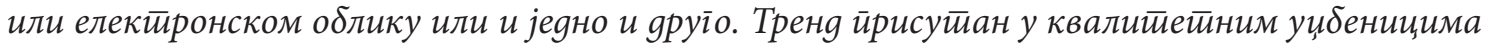

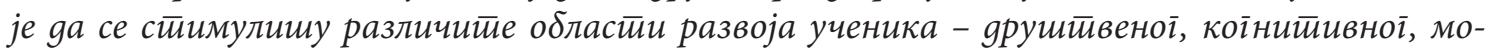

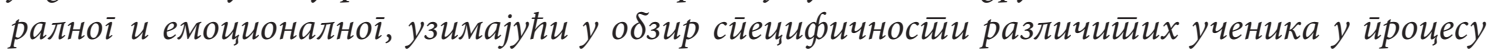
учеть. Уибеници су иррилаїођени ученицима ако узимају у обзир юихов развојни ниво, искустиво и ниво разумевана; користие одіоварајући језик; йодстичу чийане кроз разумеване;

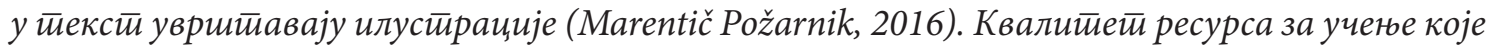

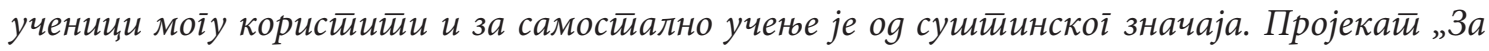

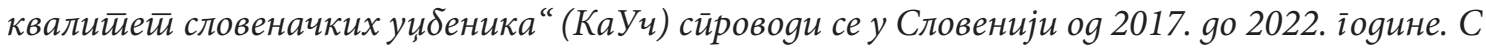

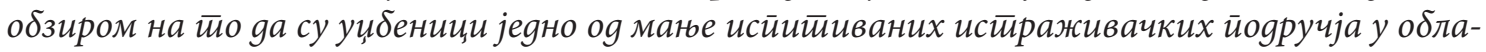

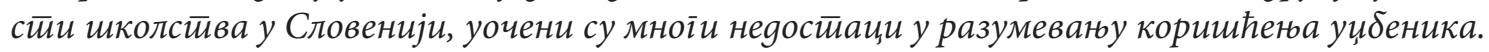

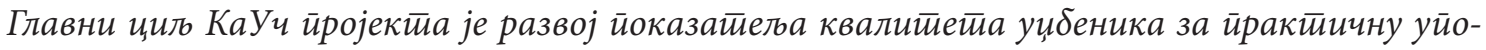

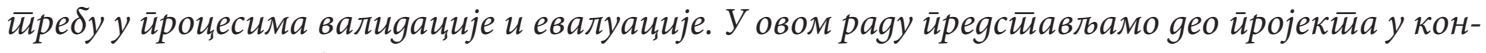

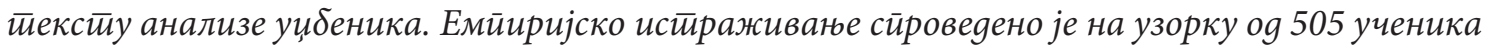
како би се анализирала уйотиреба ущбеника и раяних свезака у 4. и 5. разреgу основне школе.

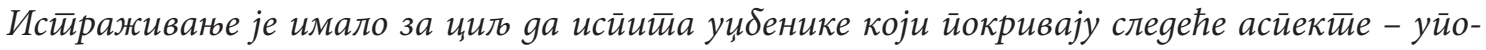

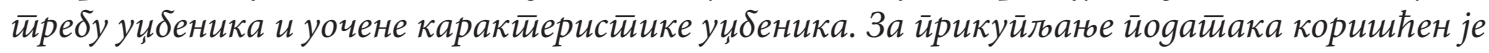

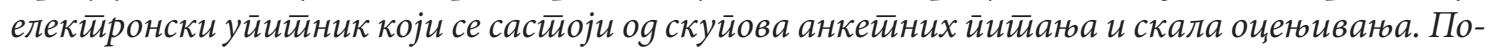

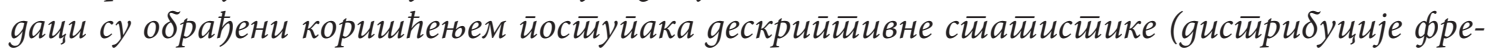




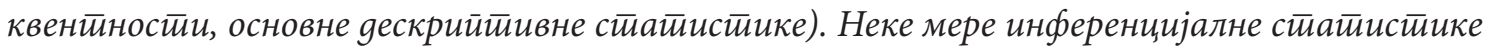
$(\bar{u}-\bar{u} е с \bar{u}$ за зависне узорке) коришћене су за ироверу односа између варијабли. На основу извршених анализа можемо закључитии gа у свим образовним иредметичма иреовлађују шимамйани уибениии. Већина ученика навоgи gа никаgа не користии, или само иовремено,

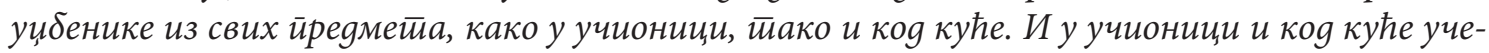
ниии најчешће користе уибенике за иррви стирани језик, науку и иехнолоіију и ярушитвене

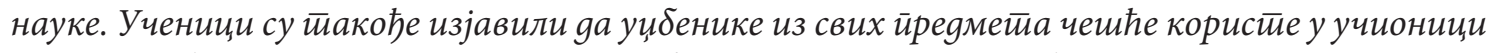
неі̄о коg куће. Према жељама ученика забележеним у анкетии, већина ученика навоgи gа им се највише gойаgају уибеници из науке и йехнолоїије, gок се најчешће користие уибеници

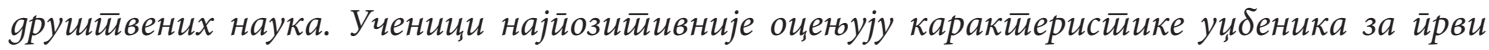

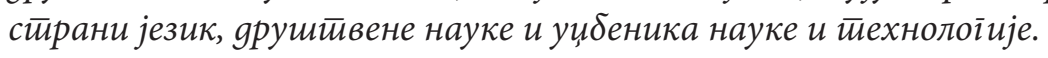

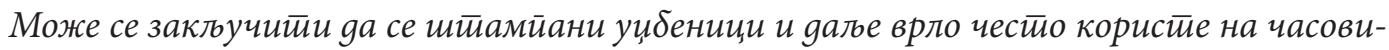
ма у 4. и 5. разреgу основне школе. Добијени резулитаии су битина основа за истираживане уйотиребе и улоіе уибеника у образовану. Наяале, у оквиру КаУч йројекйа, йакође се ис-

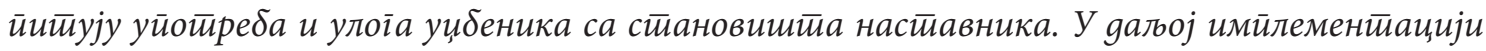

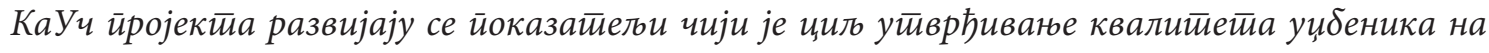
неколико образовних нивоа.

Кьучне речи: уибеник, основна школа, gияакиичка, учениии. 